\title{
Akt is involved in the inhibition of cell proliferation by EGF
}

\author{
Soung Hoo Jeon ${ }^{1}$, Woo-Jeong Jeong ${ }^{1}$, \\ Jae-Young Cho ${ }^{1}$, Kee-Ho Lee ${ }^{2}$ \\ and Kang-Yell Choi ${ }^{1,3}$ \\ ${ }^{1}$ Department of Biotechnology \\ Yonsei University \\ Seoul 120-752, Korea \\ ${ }^{2}$ Laboratory of Molecular Oncology \\ Korea Institute of Radiological and Medical Sciences \\ Seoul 139-706, Korea \\ ${ }^{3}$ Corresponding author: Tel, 82-2-2123-2887; \\ Fax, 82-2-362-7265; E-mail, kychoi@yonsei.ac.kr
}

Accepted 28 May 2007

Abbreviations: APC, adenomatos polyposis coli; BrdU, bromodeoxyuridine; DAPI, 4'6-diamidino-2-phenylindole; PI3K, phosphatidyl inositol 3-kinase

\begin{abstract}
Axin is a negative regulator of the Wnt $/ \beta$-catenin pathway and is involved in the regulation of axis formation and proliferation. Involvement of Axin in the regulation of other signaling pathways is poorly understood. In this study, we investigated the involvement of Akt in growth regulation by Axin in L929 fibroblasts stimulated by EGF. Akt activity was increased by EGF treatment and Ras activation, respectively. Both the EGFand Ras-induced Akt activations were abolished by Axin induction, as revealed by both Western blot and immunocytochemical analyses. The proliferation and Akt activation induced by EGF were decreased by Axin induction, and the effects of EGF were abolished by treatment of an Akt-specific inhibitor. Therefore, Axin inhibits EGF-induced proliferation of L929 fibroblasts by blocking Akt activation.
\end{abstract}

Keywords: Axin protein; epidermal growth factor; 1-phosphatidylinositol 3-kinase; proto-oncogene proteins c-akt; Wnt proteins

\section{Introduction}

Axin is a negative regulator in the canonical Wnt/ $\beta$-catenin signaling pathway, and was first identified as the product of the fused locus in mice (Zeng et al., 1997). Axin is involved in the regulation of proliferation and embryonic axis formation (Zeng et al., 1997). Axin is a multi-domain scaffold protein that associates directly with $\beta$-catenin, GSK3 $\beta$, and phosphatase PP2A (Hsu et al., 1999). Axin is implicated in down-regulation of $\mathrm{Wnt} / \beta$-catenin signaling (Ikeda et al., 1998; Itoh et al., 1998; Sakanaka et al., 1998; Kikuchi et al., 2006). There are two vertebrate Axins (Axin 1 and Axin 2). Axin1 is constitutively expressed, but Axin 2 is induced by active Wnt signaling and acts therefore in a negative feedback loop (Yan et al., 2001; Jho et al., 2002; Lustig et al., 2002). Overexpressed Axin destabilizes $\beta$-catenin (Behrens et al., 1998; Hart et al., 1998; Ikeda et al.,1998; Kishida et al., 1998; Nakamura et al., 1998; Sakanaka et al., 1998; Yamamoto et al., 1998). Loss of Axin results in nuclear accumulation of $\beta$-catenin followed by formation of the $\beta$-catenin-TCF transcriptional complex involving transcriptional activation of its target genes (Sakanaka et al., 1998). Mutations of Axin have been reported in hepatocellular carcinoma (Clevers, 2000; Satoh et al., 2000). However, the role and mechanism of Axin in the proliferation and transformation of cells are poorly understood.

The PI3 kinase (PI3K)-Akt signaling pathway is involved in various cellular processes including growth, metabolism, reproduction and life span (Gao et al., 2004; Kim et al., 2004; Phung et al., 2006; Stoeltzing et al., 2006). Akt/PKB, a serine/ threonine kinase, is an intermediate signaling component of the PI3K-Akt pathway, and is involved in the transmission of insulin or Ras signaling (Shepherd et al., 1998; Toker and Yoeli-Lerner, 2006). Aberrant regulation of Akt signaling is frequently observed in several human cancers, and Akt plays an important role in cancer progression (Toker and Yoeli-Lerner, 2006; Vega et al., 2006).

The ERK pathway is one of the major transforming signaling pathways, and the cross-talk between the ERK and the Wnt/ $\beta$-catenin pathways was identified in several of our previous experiments (Yun et al., 2005; Park et al., 2006; Jeon et al., 2007). The ERK pathway is immediately activated by recombinant Wnt3a (Yun et al., 2005), and is also regulated by adenomatos polyposis coli (APC), the negative regulator of the $\mathrm{Wnt} / \beta$-catenin pathway (Park et al., 2006). Although both the Wnt/ $\beta$-catenin pathway and the PI3K/Akt pathway are involved in tumor progression, the relationship between these two pathways is poorly understood. The role of Axin in anti-proliferation might be acquired by inhibition of the $\mathrm{Wnt} / \beta$-catenin pathway 
(Behrens et al., 1998; Hart et al., 1998; Ikeda et al., 1998; Kishida et al., 1998; Lustig and Behrens, 2003). However, involvement of Axin in regulations of other transforming pathways is poorly understood. We recently identified a role of Axin in the regulation of the Ras-ERK pathway and subsequent proliferation (Jeon et al., 2007). Currently, involvement of Axin in the regulation of the PI3KAkt signaling pathway is unknown.

In the present study, we investigated the role of Axin in the inhibition of EGF- or Ras-induced proliferation via Akt. Akt was activated by treatment of EGF or by overexpression of active Ras, indicating that Ras is a mediator of Akt activation by EGF signaling. The Akt activation by either Ras or EGF was abolished by doxycyclin (Dox)-induced induction of Axin. The Akt regulations by Axin were further confirmed by inhibitions of EGF- and Rasinduced nuclear localization of Akt by Axin. We identified inhibitions of the EGF- or Ras-induced proliferation and PI3K-Akt pathway activation by Akt inhibitor. These results indicate that Axin inhibits EGF- or Ras-induced cell proliferation at least partly through inhibition of the Akt pathway.

\section{Materials and Methods}

\section{Reagents}

DMEM and FBS, both antibiotics, were purchased from Invitrogen (Grand Island, NY). ERK, phospho-ERK (p-ERK), p-Akt, Akt, $\alpha$-tubulin and $\beta$ catenin antibodies were obtained from Santa Cruz Biotechnology (Santa Cruz, CA). HRP-conjugated anti-mouse IgG antibodies were acquired from Cell Signaling Biotechnology (Beverly, MA) and $\alpha$ tubulin antibodies were purchased from Oncogene Research Products (San Diego, CA). An enhanced chemiluminescence (ECL) system was obtained from Amersham Pharmacia (Uppsala, Sweden). Akt inhibitor was acquired from Calbiochem (EMD Biosciences, Germany). H-ras retrovirus was obtained from Dr. S. J. Lee at the Korean Institute of Radiological and Medical Sciences (Seoul, Korea). EGF and Dox were purchased from Sigma Aldrich (St. Louis, MO).

\section{Cells, and induction or knock down of Axin}

L929-Axin-GFP cells (Jeon et al., 2007) were grown in DMEM supplemented with $10 \%$ FBS, G418 $(200 \mu \mathrm{g} / \mathrm{ml})$, streptomycin $(100 \mu \mathrm{g} / \mathrm{ml})$, and penicillin $\mathrm{G}$ sodium $(100 \mu \mathrm{g} / \mathrm{ml})$ and incubated at $37^{\circ} \mathrm{C}$ in $5 \% \mathrm{CO}_{2}$. Axin was induced by $0.5 \mu \mathrm{g} / \mathrm{ml}$ of Dox for $24 \mathrm{~h}$ and/or stimulated with $20 \mathrm{ng} / \mathrm{ml}$ of EGF for 30 min before cell harvest. The Akt inhi- bitor $(20 \mu \mathrm{M})$ was pre-treated for $1.5 \mathrm{~h}$ before EGF treatment. For Ras activation, L929-Axin-GFP cells were infected with $\mathrm{H}$-ras retrovirus before Axin induction with $0.5 \mu \mathrm{g} / \mathrm{ml}$ of Dox for 0-4 h. To knock down Axin, cells were transfected with pAxinsiRNA (Jeon et al., 2007) using LipofectAMINE transfection reagent according to the manufacturer (Invitrogen)'s instructions, followed by further incubation of the cells for $48 \mathrm{~h}$ (Figure 1B).

\section{Western blot analysis}

In preparation of the proteins, attached cells were rinsed twice with ice-cold PBS, harvested and then lysed directly in Laemmli SDS sample buffer (Park et al., 2004). The samples were boiled and subjected to $5-10 \%$ SDS PAGE followed by Western blot analysis using anti-Axin, - $\beta$-catenin, -p-Akt, $p$ ERK, or $\alpha$-tubulin antibody followed by matching HRP conjugated secondary antibody. The protein bands were visualized by enhanced chemiluminescence (Amersham Pharmacia, Uppsala, Sweden) according to the manufacturer's instructions.

\section{Immunocytochemistry and bromodeoxyuridine incorporation}

L929 cells were grown on glass cover slips at a density of $2 \times 10^{4}$ cells/well and induced with $1 \mu \mathrm{g} / \mathrm{ml}$ Dox for $24 \mathrm{~h}$. In the cases required, the cells were treated with $10 \mathrm{ng} / \mathrm{ml}$ of EGF for $30 \mathrm{~min}$ or infected with retroviral H-ras for $24 \mathrm{~h}$. The cells were then incubated with anti-p-Akt antibody at a 1:200 dilution for $1 \mathrm{~h}$ and then treated with goat anti-rabbit-Rhodamine Red ${ }^{\mathrm{TM}}$-X-conjugated secondary antibody at a 1:1,000 dilution for $1 \mathrm{~h}$, and washed 5 times with PBS. GFP-Axin was visualized as GFP by confocal microscopic analysis. DAPI (Boehringer Mannheim, Mannheim, Germany) was then treated at a final concentration of $0.1 \mu \mathrm{g} / \mathrm{ml}$ in PBS for $10 \mathrm{~min}$, and the cells were extensively washed with PBS and mounted for photography using a Radiance 2000/MP, multiphoton imaging system (Bio-Rad, Herculus, CA). Each experiment was performed at least three times.

\section{FACS analysis for measurement of bromodeoxyuridine incorporation}

For BrdU incorporation, L929-Axin-GFP cells were seeded in 6 -well plates at $5 \times 10^{4}$ cells per well. The cells were treated with $0.5 \mu \mathrm{g} / \mathrm{ml}$ of Dox for Axin induction and/or Akt inhibitor with or without EGF. BrdU was added to achieve a final concentration of $20 \mu \mathrm{M}$ for $8 \mathrm{~h}$ before harvesting the cells. 
A

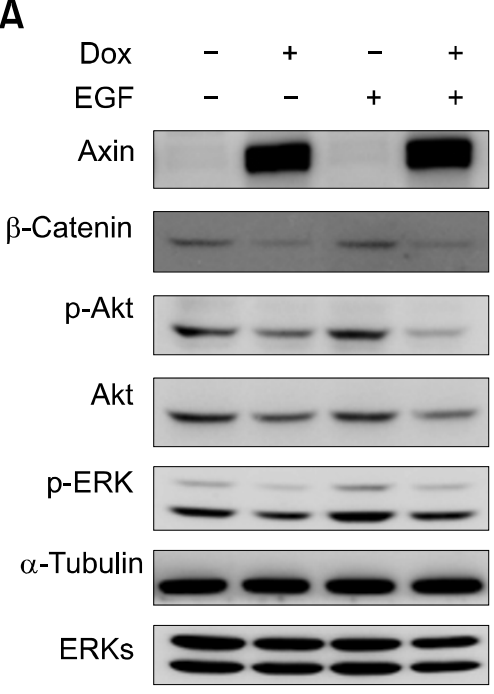

B

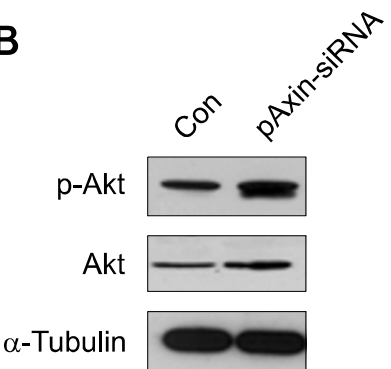

C

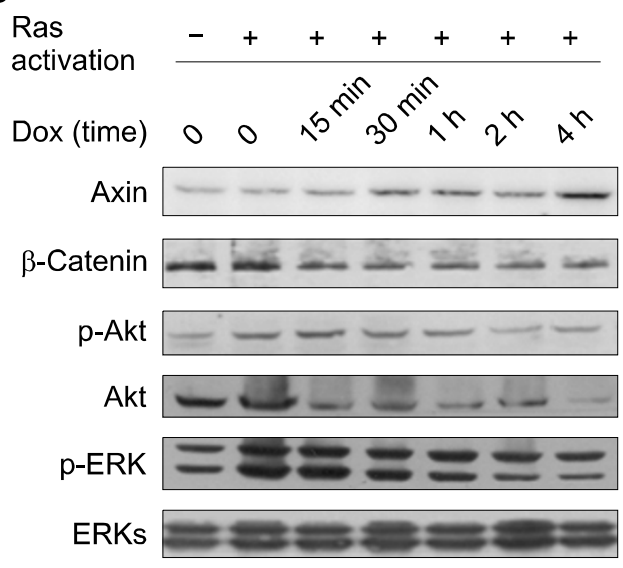

Figure 1. Effects of Axin on EGF- or Ras-induced Akt activation. (A) L929-Axin-GFP cells were grown in DMEM supplemented with $10 \%$ heat-inactivated FBS, G418 $(200 \mu \mathrm{g} / \mathrm{ml})$, streptomycin $(100 \mu \mathrm{g} / \mathrm{ml})$, and penicillin $\mathrm{G}$ sodium $(100 \mu \mathrm{g} / \mathrm{ml})$ in $5 \% \mathrm{CO}_{2}$ at $37^{\circ} \mathrm{C}$. Axin was induced by $0.5 \mu \mathrm{g} / \mathrm{ml}$ of Dox treatment for $48 \mathrm{~h}$. Where required, the cells were treated with $20 \mathrm{ng} / \mathrm{ml}$ of EGF for $30 \mathrm{~min}$ before harvesting the cells. (B) Effects of Axin siRNA on Akt activity. L929 cells were grown to $3 \times 10^{5}$ confluence as described in Figure $1 \mathrm{~A}$, and transiently transfected with either an empty vector or the Axin siRNA vector, as described in Materials and Methods (Jeon et al., 2007). (C) L929-Axin-GFP cells were grown as shown in Figure $1 \mathrm{~A}$, infected with retroviral $H$-ras, and induced with $0.5 \mu \mathrm{g} / \mathrm{ml}$ of Dox for $0-4 \mathrm{~h}$. The cell extracts were resolved on 10\% SDS-PAGE, and Axin, Akt, $\beta$-catenin, p-Akt, p-ERKs, and ERKs proteins were detected by Western blot analysis. The blots for Axin, $\beta$-catenin, $p$-ERK in Figure $1 \mathrm{~B}$ are described in previous study (Jeon et al., 2007) and were not provided here.

For quantification of the BrdU, the cells were fixed with $3.7 \%$ paraformaldehyde for $20 \mathrm{~min}$ at room temperature, permeabilized with permeabilization buffer (phosphate-buffered saline without $\mathrm{Mg}^{2+}$ and $\mathrm{Ca}^{2+}, 1 \% \mathrm{FBS}, 0.1 \%$ saponin), then incubated with anti-BrdU monoclonal antibody, and subsequently with tetramethyl-rhodamine (TRITC)-conjugated goat anti-rabbit IgG (Jackson Immuno Research Laboratories, West Grove, PA). The cell cycle profile was determined using a Becton Dickinson FACS Caliber with the Cell Quest Version 3.3 program (Becton-Dickinson Immunocytometry Systems, San Jose, CA).

\section{Results and Discussion}

Coordinated regulation of intra-cellular signaling pathways is central to the ability of mitogens and oncogenes to promote proliferation (Jones and Kazlauskas, 2001). Both Ras and Akt are important for normal growth of cells, and the combined activity of these two proteins results in malignant transformation (Parsa and Holland, 2004). Wnt/ $\beta$ catenin is one other signaling pathway involving cellular transformation, and mutations of the genes for the components of this pathway, such as adenomatos polyposis coli, Axin, and $\beta$-catenin, often result in various human cancers (Kitaeva et al., 1997; Miyoshi et al., 1998). The Wnt/ $\beta$-catenin cross-talk with other growth-regulating signaling 
pathways is poorly understood. In this study, we identified a role of Axin, a negative regulator of Wnt/ $\beta$-catenin signaling, in regulation of the PI3KAkt pathway in L929 fibroblast cells. We further revealed the involvement of PI3K-Akt pathway regulation by $A x i n$ in anti-proliferation.

\section{Axin inhibits EGF- and Ras-induced Akt activation}

To understand the role of the PI3K-Akt pathway in Axin-induced inhibition of EGF- or Ras-induced proliferation, we monitored the activation status of Akt in Axin-induced L929 cells, either under EGF conditions or not. $\beta$-Catenin was reduced by Axin induction, indicating the normal functionality of Axin (Figure 1A). The p-Akt, which represents the activation status of Akt, was reduced by Dox-induced Axin induction within L929 cells (Figure 1A). The ERK activity was also decreased by Axin induction, as previously observed (Jeon et al., 2007). The p-Akt was increased by small interference RNA (siRNA)-mediated Axin knock down (Figure 1B) as the level of p-ERK (Jeon et al., 2007), further confirming the role of Axin in Akt inhibition.

ERK is an important mediator of EGF- and Ras-induced proliferation and transformation, and transmits cytosolic cellular signaling into nuclei (Hao and Schwaber, 2006; Planque, 2006). The level of $p$-Akt was increased by treatment of EGF or retroviral Ras infection (Figures $1 \mathrm{~A}$ and $1 \mathrm{C}$ ), which result agrees with a previous observation indicating that Akt could be a downstream component of Ras (Lopez-Hernandez and Santos, 1999). We monitored the effects of Axin induction on either EGF- or Ras-induced Akt activation. Both the Akt and ERK activations by EGF were reduced by Axin induction (Figure $1 \mathrm{~A}$ ). The Akt activation by Ras activation was also step-wisely reduced by incremental Axin induction (Figure 1C).
These results indicate that Axin might be involved in the inhibition of EGF- or Ras-induced Akt activation. The Akt protein levels were also reduced by Axin induction in Ras-activated cells (Figure 1C). The Akt gene, retaining a Tcf- $4 / \beta$-catenin binding site in its promoter, was subjected to regulation by Wnt/ $\beta$-catenin signaling (Dihlmann et al., 2005). The fold regulation of Akt was somewhat lower than that of $p$-Akt in cells overexpressed by Axin (Figures $1 \mathrm{~A}$ and $1 \mathrm{C}$ ). Therefore, Akt regulation by Axin occurs at the levels both of transcription and cellular signaling involving phosphorylation.

\section{Axin inhibits EGF- or Ras-induced nuclear localization of active Akt}

To further investigate the role of Axin in EGF- or Ras-induced Akt activation, we monitored the localization of $\mathrm{p}-\mathrm{Akt}$, the activated form of Akt, by immunocytochemical analysis in Axin-induced cells by Dox. The p-Akt was localized in both the nucleus and the cytoplasm with relative enrichment in the nucleus of the L929 cells (Figure 2; upper panel). The p-Akt was significantly increased, especially in the cell nuclei by EGF treatment (Figure 2; lower panel). Both endogenous nuclear p-Akt and EGF-induced nuclear p-Akt were mostly abolished in the Axin-induced cells by Dox treatment (Figure 2, an Axin-induced cell is indicated by an arrow head). To further understand Akt regulation by Axin, we also measured the effect of Axin induction on the sub-cellular localization of $\mathrm{p}$-Akt in Ras-activated cells. The p-Akt was mostly localized in the cell nuclei in which Ras was overexpressed by the retroviral induction system (Figure 3). The Ras-induced nuclear localization of p-Akt, however, was mostly abolished by induction of Axin overexpression (Figure 3; lower panel). These immunocytochemical studies showing the

\section{DAPI}

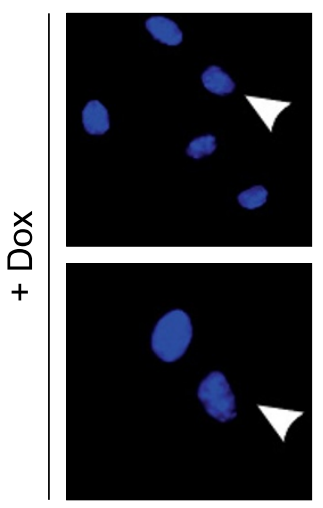

Axin

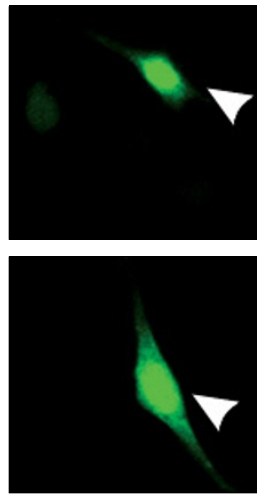

p-Akt

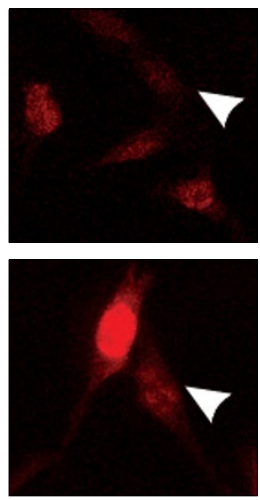

MERGE

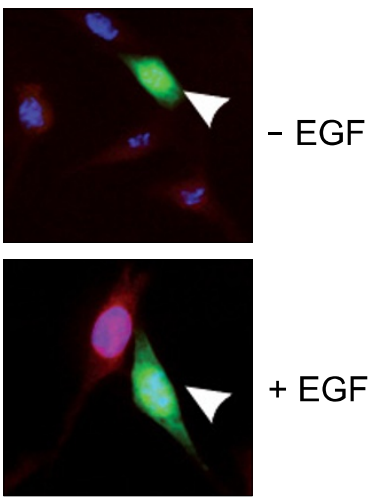

Figure 2. Effect of Axin induction on active Akt localization in L929 fibroblast cells stimulated with EGF. L929-Axin-GFP cells were grown in DMEM, and non-induced or induced with $0.5 \mu \mathrm{g} / \mathrm{ml}$ of Dox for $24 \mathrm{~h}$. In the required cases, the cells were treated with $20 \mathrm{ng} / \mathrm{ml}$ of EGF $30 \mathrm{~min}$ before immunocytochemical analyses. The cells were incubated with p-Akt antibody followed by labeling with anti-TRITC for $p$-Akt detection. GFP-Axin was visualized as GFP by confocal microscopic analysis. The cell nuclei were stained with DAPI. 

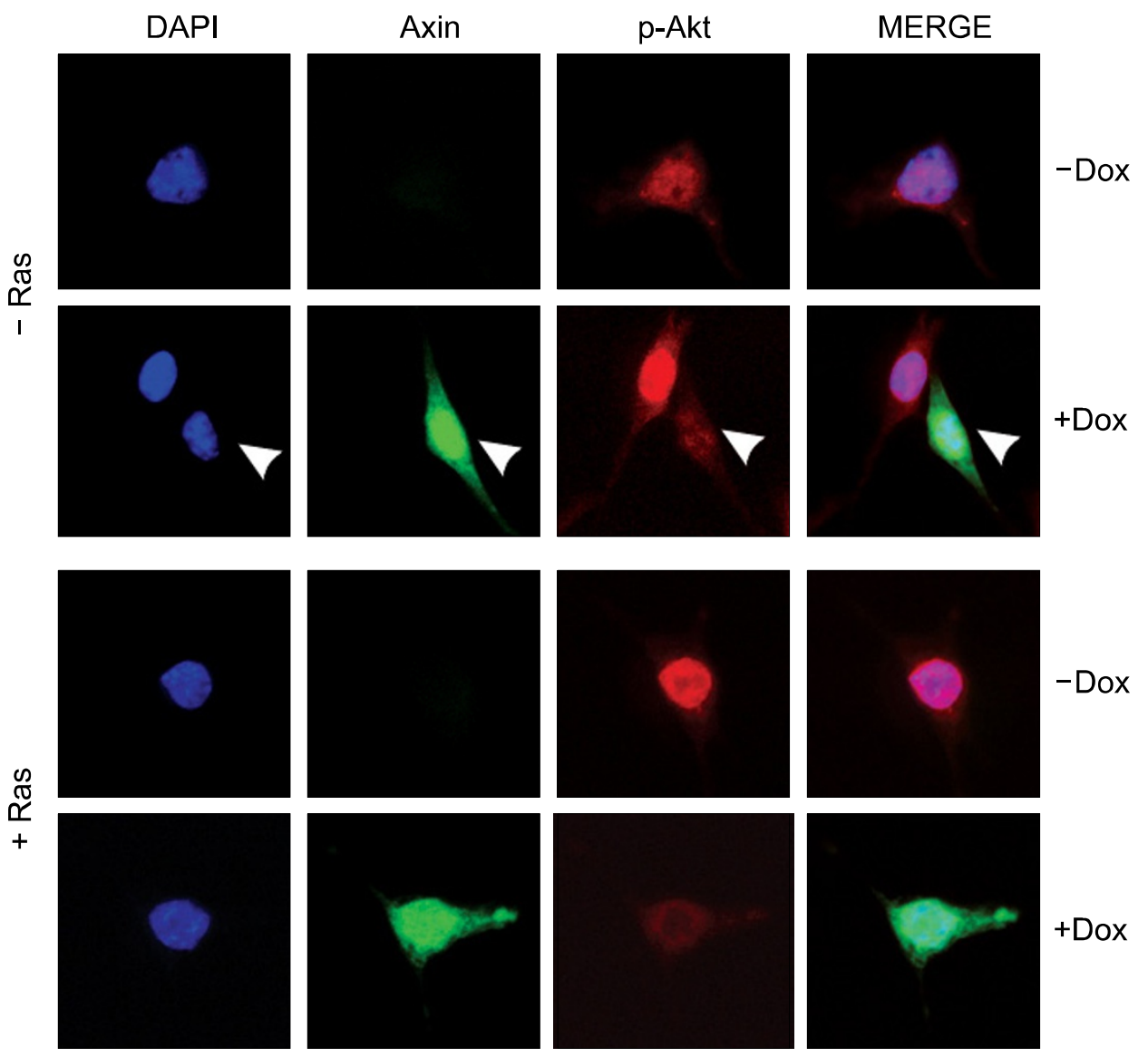

Figure 3. Effect of Axin induction on Ras-induced nuclear localization of active Akt. L929-AxinGFP cells were grown in DMEM and infected with retroviral $H$-ras, and cells were non-induced or induced with $0.5 \mu \mathrm{g} / \mathrm{ml}$ of Dox for 24 $h$. The cells were incubated with p-Akt antibody followed by labeling with anti-TRITC for p-Akt detection. GFP-Axin was visualized as GFP by confocal microscopic analysis. The cell nuclei were stained with DAPI.

inhibition of nuclear localized Akt by Axin correlate well with biochemical studies showing the role of Axin in the regulation of Akt activity (Figure 1).

\section{Axin inhibits Ras- or EGF-induced proliferation of L929 fibroblasts at least partly by reduction of Akt activation}

To investigate the role of Axin in the regulation of Ras-induced proliferation, we measured the effects of Axin induction on proliferation by Ras (Figure 4). The percentages of BrdU-incorporating cells were increased by infection of viral H-ras ${ }^{\mathrm{V} 12}$. Both basal and Ras-induced cell proliferation were decreased by Axin induction, indicating Axin's involvement in anti-proliferation. We also performed a FACS analysis for quantitative measurements of BrdU incorporation in order to identify the role of Akt in the EGF-induced proliferation of cells (Figure 5). The proliferation of L929 fibroblast cells was significantly increased by EGF treatment, and was significantly blocked by Axin induction or Akt inhibition through a specific chemical inhibitor (Figure 5). Moreover, the EGF-induced proliferations were

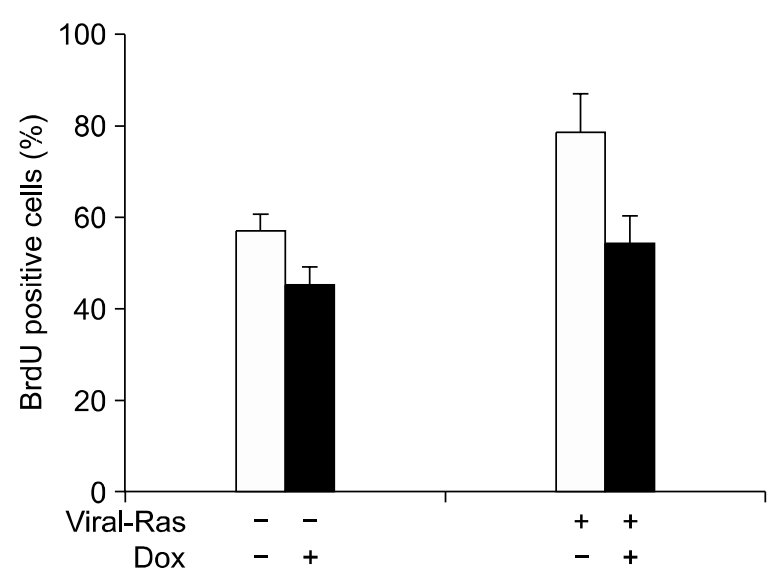

Figure 4. Effects of Axin induction on Ras-induced proliferation of L929 cells. L929-Axin-GFP cells were grown in DMEM containing $10 \% \mathrm{FBS}$ at $1 \times 10^{4}$ cells per well in 6 -well plates. The cells were infected with retroviral $\mathrm{H}$-ras, and induced with $0.5 \mu \mathrm{g} / \mathrm{ml}$ of Dox. Twenty-four $\mathrm{h}$ after transfection, BrdU was added at a final concentration of $20 \mu \mathrm{M}$ for $8 \mathrm{~h}$. The cells were visualized by immunocytochemistry (Yun et al., 2005), and the BrdU-positive cells were quantified. White and black bars represents cells not treated and treated with Dox, respectively. Error bar indicates the standard deviations of three independent analyses. 
A
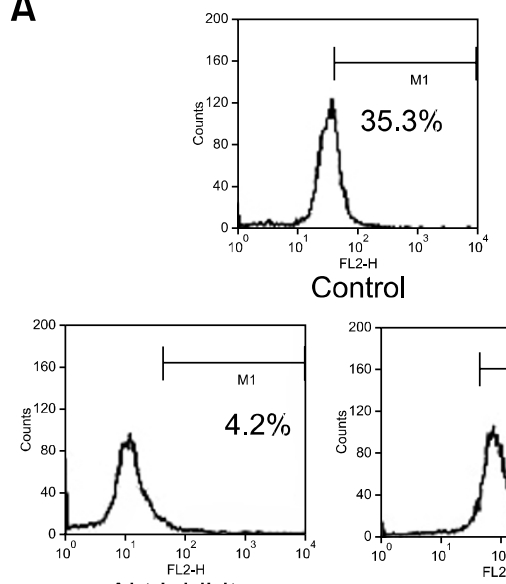

Akt inhibitor

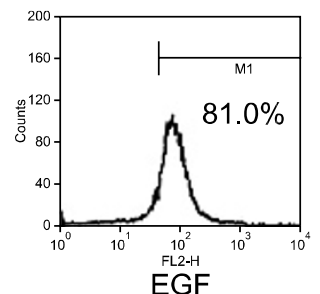

EGF

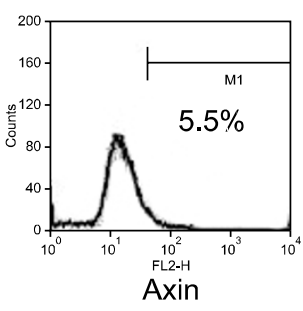

Axin

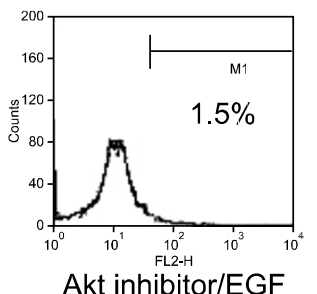

B

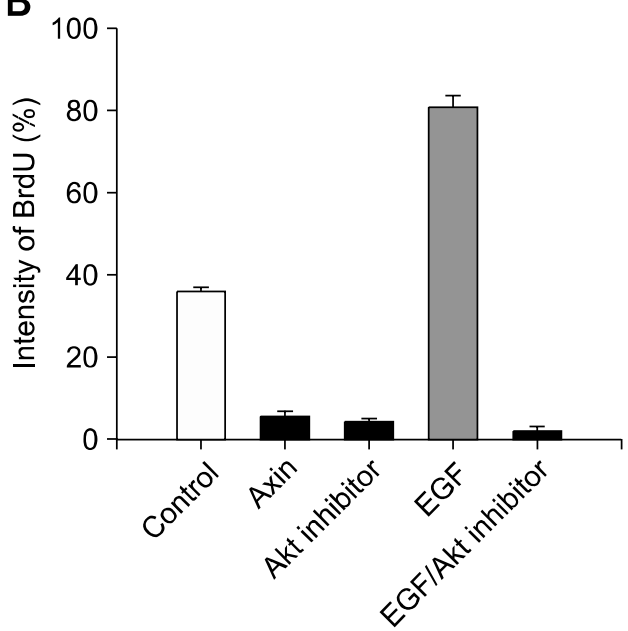

Figure 5. Effects of Axin induction on EGF-induced proliferation in L929 cells. (A) Axin-inducible cells were grown and treated either with Dox or Akt inhibitor together with or without EGF treatment. The cells were fixed, permeabilized, and incubated with BrdU antibody and subsequently with TRITC-conjugated goat anti-rabbit lgG. The relative intensities of TRITC-conjugated BrdU were measured using a FACS Vantage system (Becton-Dickinson Immunocytometry). (B) The Figure (right panel) illustrates the results of a quantitative analysis of the data. Each data point represents the average of three independent analyses.

mostly blocked by treatment of the Akt inhibitor (Figure 5). Therefore, it could be concluded that the PI3K-Akt pathway is involved in cellular proliferation induced by EGF. Axin is involved in the proliferation and transformation induced by EGF or Ras, and the Axin effects are at least partly acquired by inhibition of the ERK pathway (Jeon et al., 2007). The inhibition of EGF-induced proliferation by Akt inhibitor in this study indicates the involvement of the PI3K-Akt pathway in proliferation induced by EGF or Ras. These results further indicate the role of the PI3K-Akt pathway in the inhibition of EGF-induced proliferation by Axin. The basal level of Akt activity was reduced by Axin induction through Dox treatment or Akt-inhibitor treatment (Figure 6). Moreover, EGF-induced Akt activation was significantly reduced by co-treatment of Akt inhibitor. These results reflect the role of Axin in inhibition of EGF-induced proliferation of L929 fibroblasts via Akt. Therefore, Axin regulates the growth of fibroblasts by EGF or Ras via inhibition of both the Ras-ERK and Akt pathways. Interestingly, both the basal and EGF-induced ERK activities were also inhibited by Akt inhibitor (Figure 6 ), and that might have been due to the cross-talk between the PI3K-Akt and Ras-ERK pathways (Sasaki et al., 2003; Kim et al., 2004).

Both Ras and Akt are important to the normal growth of cells, and the combined activity of these two proteins results in malignant transformation (Parsa and Holland, 2004). Inappropriate activation of Ras and/or its downstream effecter Raf or the

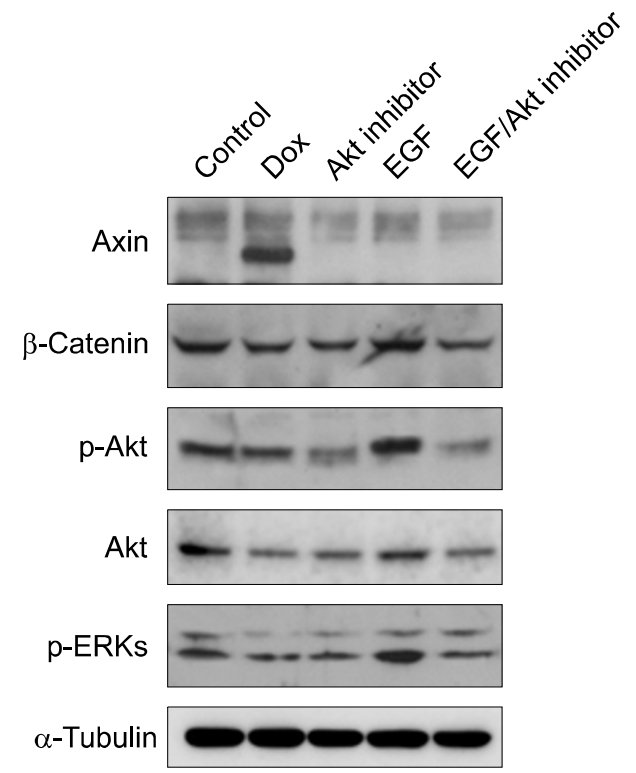

Figure 6. Effects of Akt inhibitor on EGF-induced Akt activation in L929 cells. L929-Axin-GFP cells were grown as shown in Figure 1A. The cells were induced with $0.5 \mu \mathrm{g} / \mathrm{ml}$ of Dox for $24 \mathrm{~h}$ or treated with Akt inhibitor for $2 \mathrm{~h}$ with or without EGF treatment, as described in Materials and Methods. The cell extracts were resolved on $10 \%$ SDS-PAGE, and Axin, $\beta$-catenin, $p$-Akt, $p$-ERKs, and $\alpha$-tubulin proteins were detected by Western blot analysis.

PI3K-Akt pathway is a common feature of a wide variety of human cancers (Jones and Kazlauskas, 2001). Axin mutations occur in various cancers including colorectal cancer (CRC), ovarian endo- 
metrioid adenocarcinomas and hepatocellular carcinoma (HCC) (Behrens et al., 1998; Lustig et al., 2002; Oving and Clevers, 2002; Taniguchi et al., 2002; reviewed in Lustig and Behrens, 2003).

In this paper, we identify a negative role of Axin in PI3K-Akt pathway activation and proliferation induced by EGF or Ras in L929 fibroblast cells. We indicate the potential involvement of the PI3KAkt pathway in tumorigenesis caused by mutation(s) of the components of the Wnt/ $\beta$-catenin signaling pathway.

\section{Acknowledgements}

This work was supported by the Korea Science and Engineering Foundation (KOSEF) grant funded by the Korea government (MOST) (No. 2005-01564; 2006-02681; R112000078010020).

\section{References}

Behrens J, Jerchow BA, Wurtele M, Grimm J, Asbrand C, Wirtz R, Kuhl M, Wedlich D, Birchmeier W. Functional interaction of an axin homolog, conductin, with beta-catenin, APC, and GSK3beta. Science 1998;280:596-9

Cannon ML, Cesarman E. The KSHV G protein-coupled receptor signals via multiple pathways to induce transcription factor activation in primary effusion lymphoma cells. Oncogene 2004;23:514-23

Clevers H. Axin and hepatocellular carcinomas. Nat Genet 2000;24:206-8

Dihlmann S, Kloor M, Fallsehr C, von Knebel Doeberitz M. Regulation of AKT1 expression by beta-catenin/Tcf/Lef signaling in colorectal cancer cells. Carcinogenesis 2005; 26:1503-12

Gao N, Flynn DC, Zhang Z, Zhong XS, Walker V, Liu KJ, Shi $X$, Jiang $B H$. G1 cell cycle progression and the expression of $\mathrm{G} 1$ cyclins are regulated by PI3K/AKT/mTOR/p70S6K1 signaling in human ovarian cancer cells. Am J Physiol Cell Physiol 2004;287:281-91

Hao H, Schwaber J. Epidermal growth factor receptor induced Erk phosphorylation in the suprachiasmatic nucleus. Brain Res 2006;1088:45-8

Hart MJ, de los Santos R, Albert IN, Rubinfeld B, Polakis P. Downregulation of beta-catenin by human Axin and its association with the APC tumor suppressor, beta-catenin and GSK3 beta. Curr Biol 1998;8:573-81

Hsu W, Shakya R, Costantini F. Identification of a domain of Axin that binds to the serine/threonine protein phosphatase 2A and a self-binding domain. J Biol Chem 1999;274: 3439-45

Ikeda S, Kishida S, Yamamoto H, Murai H, Koyama S, Kikuchi A. Axin, a negative regulator of the Wnt signaling pathway, forms a complex with GSK-3beta and beta-catenin and promotes GSK-3beta-dependent phosphorylation of beta- catenin. EMBO J 1998;17:1371-84

Itoh K, Krupnik VE, Sokol SY. Axis determination in Xenopus involves biochemical interactions of axin, glycogen synthase kinase 3 and beta-catenin. Curr Biol 1998;8:591-4

Jeon SH, Yun JY, Park YN, Jeong WJ, Kim S, Jho EH, Surh YJ, Choi KY. Axin inhibits extracellular signal-regulated kinase pathway by Ras degradation via beta-catenin. J Biol Chem 2007;282:14482-92

Jho EH, Zhang T, Domon C, Joo CK, Freund JN, Costantini F. Wnt/beta-catenin/Tcf signaling induces the transcription of Axin2, a negative regulator of the signaling pathway. Mol Cell Biol 2002;22:1172-83

Jiang $Q$, Zhou $C, B i Z$, Wan Y. EGF-induced cell migration is mediated by ERK and PI3K/AKT pathways in cultured human lens epithelial cells. J Ocul Pharmacol Ther 2006; 22:93-102

Jones SM, Kazlauskas A. Growth factor-dependent signaling and cell cycle progression. FEBS Lett 2001;490:110-6

Kauffmann-Zeh A, Rodriguez-Viciana P, Ulrich E, Gilbert C, Coffer P, Downward J, Evan G. Suppression of c-Mycinduced apoptosis by Ras signalling through $\mathrm{PI}(3) \mathrm{K}$ and PKB. Nature 1997;385:544-8

Kikuchi A, Kishida S, Yamamoto $H$. Regulation of Wnt signaling by protein-protein interaction and post-translational modifications. Exp Mol Med 2006;38:1-10

Kim SE, Cho JY, Kim KS, Lee JS, Choi KY. Drosophila PI3 kinase and Akt involved in insulin-stimulated proliferation and ERK pathway activation in Schneider cells Cell Signaling 2004;16:1309-17

Kim SE, Lee WJ, Choi KY. The PI3 kinase-Akt pathway mediates Wnt3a-induced proliferation. Cell Signaling 2007; 19:511-8

Kishida S, Yamamoto H, Ikeda S, Kishida M, Sakamoto I, Koyama S, Kikuchi A. Axin, a negative regulator of the wnt signaling pathway, directly interacts with adenomatous polyposis coli and regulates the stabilization of beta-catenin. J Biol Chem 1998;273:10823-6

Kitaeva MN, Grogan L, Williams JP, Dimond E, Nakahara K, Hausner P, DeNobile JW, Soballe PW, Kirsch IR. Mutations in beta-catenin are uncommon in colorectal cancer occurring in occasional replication error-positive tumors. Cancer Res 1997;57:4478-81

Lopez-Hernandez E, Santos E. Oncogenic Ras-induced germinal vesicle breakdown is independent of phosphatidylinositol 3-kinase in Xenopus oocytes. FEBS Lett 1999;451:284-8

Lustig B, Jerchow B, Sachs M, Weiler S, Pietsch T, Karsten $\mathrm{U}$, van de Wetering M, Clevers H, Schlag PM, Birchmeier W, Behrens J. Negative feedback loop of Wnt signaling through upregulation of conductin/axin2 in colorectal and liver tumors. Mol Cell Biol 2002;22:1184-93

Lustig B, Behrens J. The Wnt signaling pathway and its role in tumor development. J Cancer Res Clin Oncol 2003; 129:199-221

Miyoshi, Y, Iwao, K, Nagasawa, Y, Aihara, T, Sasaki, Y, 
Imaoka, S, Murata, M, Shimano, T, Nakamura, Y. Activation of the beta-catenin gene in primary hepatocellular carcinomas by somatic alterations involving exon 3 . Cancer Res 1998:58:2524-7

Nakamura T, Hamada F, Ishidate T, Anai K, Kawahara K, Toyoshima K, Akiyama T. Axin, an inhibitor of the Wnt signalling pathway, interacts with beta-catenin, GSK-3beta and APC and reduces the beta-catenin level. Genes Cells 1998;3:395-403

Oving IM, Clevers HC. Molecular causes of colon cancer. Eur J Clin Invest 2002;32:448-57

Park KS, Jeon SH, Oh JW, Choi KY. Cip/WAF1activation is an important factor for the ERK pathway dependent antiproliferation of colorectal cancer cells. Exp Mol Med 2004; 36:557-66

Park KS, Jeon SH, Kim SE, Bahk YY, Holmen SL, Williams BO, Chung KC, Surh YJ, Choi KY. APC inhibits ERK pathway activation and cellular proliferation induced by Ras. J Cell Sci 2006;119:819-27

Parsa AT, Holland EC. Cooperative translational control of gene expression by Ras and Akt in cancer. Trends Mol Med 2004;10:607-13

Phung TL, Ziv K, Dabydeen D, Eyiah-Mensah G, Riveros M, Perruzzi C, Sun J, Monahan-Earley RA, Shiojima I, Nagy JA, Lin MI, Walsh K, Dvorak AM, Briscoe DM, Neeman M, Sessa WC, Dvorak HF, Benjamin LE. Pathological angiogenesis is induced by sustained Akt signaling and inhibited by rapamycin. Cancer Cell 2006;10:89-91

Planque N. Nuclear trafficking of secreted factors and cellsurface receptors: new pathways to regulate cell proliferation and differentiation, and involvement in cancers. Cell Commun Signal 2006;4:7

Rodriguez-Viciana $\mathrm{P}$, Warne $\mathrm{PH}$, Khwaja A, Marte BM, Pappin D, Das P, Waterfield MD, Ridley A, Downward J. Role of phosphoinositide 3-OH kinase in cell transformation and control of the actin cytoskeleton by Ras. Cell 1997;89:457-67

Sakanaka C, Weiss JB, Williams LT. Bridging of beta-catenin and glycogen synthase kinase-3beta by axin and inhibition of beta-catenin-mediated transcription. Proc Natl Acad Sci USA 1998; $95: 3020-3$

Sasaki A, Taketomi T, Kato R, Saeki K, Nonami A, Sasaki M, Kuriyama M, Saito N, Shibuya M, Yoshimura A. Mammalian Sprouty4 suppresses Ras-independent ERK activation by binding to Raf1. Nat Cell Biol 2003;5:427-32
Satoh S, Daigo Y, Furukawa Y, Kato T, Miwa N, Nishiwaki T, Kawasoe T, Ishiguro H, Fujita M, Tokino T, Sasaki Y, Imaoka S, Murata M, Shimano T, Yamaoka Y, Nakamura Y. AXIN1 mutations in hepatocellular carcinomas, and growth suppression in cancer cells by virus-mediated transfer of AXIN1. Nat Genet 2000;24:245-50

Shepherd PR, Withers DJ, Siddle K. Phosphoinositide 3-Kinase: the key switch mechanism in insulin signaling. Biochem J 1998;333:471-90

Stoeltzing O, Meric-Bernstam F, Ellis LM. Intracellular signaling in tumor and endothelial cells: the expected and, yet again, the unexpected. Cancer Cell 2006;10:159-70

Taniguchi K, Roberts LR, Aderca IN, Dong X, Qian C, Murphy LM, Nagorney DM, Burgart LJ, Roche PC, Smith DI, Ross JA, Liu W. Mutational spectrum of beta-catenin, AXIN1, and AXIN2 in hepatocellular carcinomas and hepatoblastomas. Oncogene 2002;21:4863-71

Toker A, Yoeli-Lerner M. Akt signaling and cancer: surviving but not moving on. Cancer Res 2006;66:3963-6

Vega F, Medeiros LJ, Leventaki V, Atwell C, Cho-Vega JH, Tian L, Claret FX, Rassidakis GZ. Activation of mammalian target of rapamycin signaling pathway contributes to tumor cell survival in anaplastic lymphoma kinase-positive anaplastic large cell lymphoma. Cancer Res 2006;66:6589-97

Yamamoto H, Kishida S, Uochi T, Ikeda S, Koyama S, Asashima M, Kikuchi A. Axil, a member of the Axin family, interacts with both glycogen synthase kinase 3beta and beta-catenin and inhibits axis formation of Xenopus embryos. Mol Cell Biol 1998;18:2867-75

Yan D, Wiesmann M, Rohan M, Chan V, Jefferson AB, Guo L, Sakamoto D, Caothien RH, Fuller JH, Reinhard C, Garcia PD, Randazzo FM, Escobedo J, Fantl WJ, Williams LT. Elevated expression of axin2 and hnkd mRNA provides evidence that $\mathrm{Wnt} /$ beta-catenin signaling is activated in human colon tumors. Proc Natl Acad Sci USA 2001;98: 14973-8

Yun MS, Kim SE, Jeon SH, Lee JS, Choi KY. Both ERK and $\mathrm{Wnt} /$ beta-catenin pathways are involved in Wnt3a-induced proliferation. J Cell Sci 2005;118:313-22

Zeng L, Fagotto F, Zhang T, Hsu W, Vasicek TJ, Perry WL 3rd, Lee JJ, Tilghman SM, Gumbiner BM, Costantini F. The mouse Fused locus encodes Axin, an inhibitor of the Wnt signaling pathway that regulates embryonic axis formation. Cell 1997;90:181-92 